Available online on 15.04.2020 at http://jddtonline.info
Open Access to Pharmaceutical and Medical Research
unrestricted non-commercial use, provided the original work is properly cited

Open@ Access

Review Article

\title{
A Concise Review Based on Analytical Method Development and Validation of Apremilast in Bulk and Marketed Dosage Form
}

\author{
Saurabh C. Khadse'1, Shailesh S. Chalikwar², Sandip D. Firke', Harshal R. Baviskar², Akshay D. Umale ${ }^{2}$ \\ ${ }^{1}$ Dept. of Pharmaceutical Chemistry, RCPIPER, Shirpur, INDIA, 425405 \\ ${ }^{2}$ Dept. of Quality Assurance, RCPIPER, Shirpur, INDIA, 425405
}

\begin{abstract}
Apremilast is used for treatment of psoriasis and psoriatic arthritis. It may also be beneficial for other inflammatory diseases relevant to the immune system. The drug functions as a selective enzyme phosphodiesterase 4 (PDE4) inhibitor and avoids the spontaneous development of TNF-alpha from human synovial rheumatoid cells. The present review assesses the different approaches for evaluation of apremilast in bulk material as well as different formulations. A concise review consists of compile and discuss about over 30 methods for analysing apremilast in the biological matrices, the samples of bulk and in different dosage formulations including HPLC, HPTLC, UPLC, LC-MS and UV-spectrophotometry. A concise review represents the compilation and discussion of about more than 30 analytical methods which includes HPLC, HPTLC, UPLC, LC-MS and UV-Spectrophotometry methods implemented for investigation of apremilast in biological matrices, bulk samples and in different dosage formulations. This detailed review will be of great help to the researcher who is working on apremilast.
\end{abstract}

Keywords: Apremilast; Analytical Profile; HPLC; HPTLC; Bioanalytical; Stability indicating

Article Info: Received 30 Jan 2020; Review Completed 11 March 2020; Accepted 23 March 2020; Available online 15 April 2020

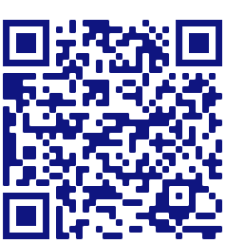

Cite this article as:

Khadse SC, Chalikwar SS, Firke SD, Baviskar HR, Umale AD, A Concise Review Based on Analytical Method Development and Validation of Apremilast in Bulk and Marketed Dosage Form, Journal of Drug Delivery and Therapeutics. 2020; 10(2s):175-182 http://dx.doi.org/10.22270/jddt.v10i2-s.4012

\section{*Address for Correspondence:}

Harshal R. Baviskar, R. C. Patel Institute of Pharmaceutical Education and Research, Shirpur, Dhule (MS), India 425405, Tel: 7038871599, 9511783842

\section{Introduction of Apremilast:}

Chemically, Apremilast is known as N-[2-[(1S)-1-(3-ethoxy4methoxyphenyl)-2-(methylsulfonyl) ethyl]-1,3-dioxo2,3dihydro-1H-isoindol-4-yl] acetamide. It has a C22H24N207S and a molecular weight of $460.5 \mathrm{~g}$ mole. (1). Apremilast is a drug approved by the Food and Drug Administration, used for psoriasis and psoriatic arthritis treatment. It may also be beneficial for other inflammatory diseases related to the immune system. The drug functions as a potent phosphodiesterase 4 (PDE4) enzyme inhibitor and prevents the spontaneous development of TNF-alpha from human synovial rheumatoid cells. (2) Apremilast is Phthalimide derivative. It is a white to pale yellow, nonhygroscopic powder that is virtually insoluble at a wide range of $\mathrm{pH}$ in water and buffer solutions but is soluble in lipophilic solvents including acetonitrile, butanone, acetone, dichloromethane, and tetrahydrofuran. It is manufactured in India by Glenmark Pharmaceutical, under the brand name Otezla and Aprezo (3). Apremilast chemical structure has been adequately demonstrated by elemental analysis. IR and UV spectroscopy, $1 \mathrm{H}$ and 13C NMR spectroscopy, mass spectrometry, single crystal X-ray diffraction and XRPD,
DSC,TGA,DVS and particle size distribution, as well as polymorphism system (characterized by XRPD, DSC, TGA, DVS, TGA/FT-IR and microscopic testing) Apremilast shows stereoisomerism due to the presence of a single chiral centre, with the pharmacologically active (S)-enantiomer. Effective drug stability tests and clinical studies have shown that Apremilast (S)-enantiomer is not interconverted to its (R)enantiomer both on storage and in vivo. Polymorphism and seven polymorphic forms were observed for Apremilast (designated $A-G$ ) was named for the active substance. The desirable type $\mathrm{B}$ was found to be the most anhydrous form of Apremilast which is thermodynamically stable. The production cycle consistently yields single crystal type B active substance. (4)

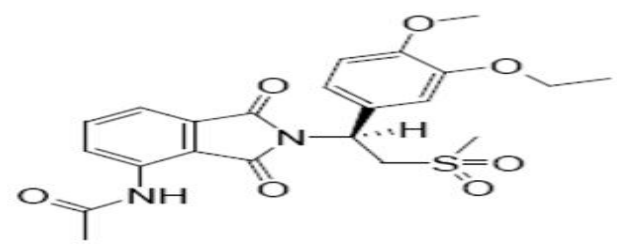

Fig1. Structure of Apremilast. 
Table 1: Drug profile of Apremilast:

\begin{tabular}{|c|c|}
\hline Drug Name & Apremilast \\
\hline Category & $\begin{array}{l}\text { Phoshodiesterase4 (PDE4). } \\
\text { Immunomodulating agent. }\end{array}$ \\
\hline Chemical formula & $\mathrm{C}_{22} \mathrm{H}_{24} \mathrm{~N}_{2} \mathrm{O}_{7} \mathrm{~S}$ \\
\hline IUPAC Name & $\begin{array}{c}\mathrm{N}-[2-[(1 \mathrm{~S})-1-(3 e t h o x y-4- \\
\text { methoxyphenyl)-2- } \\
\text { methylsulfonylethyl]- } \\
\text { 1,3dioxoisoindol-4-yl] acetamide. }\end{array}$ \\
\hline Molecular weight & $460.501 \mathrm{~g} / \mathrm{mol}$ \\
\hline Melting point & $156-158^{\circ} \mathrm{C}$. \\
\hline Solubility & $\begin{array}{l}\text { slightly soluble in water, sparingly } \\
\text { soluble in Acetonitrile and Methanol. }\end{array}$ \\
\hline Half life & $6-9$ hours \\
\hline Pak value & $\begin{array}{l}\text { Strongest acid- } 14.42 \\
\text { Strongest base- } 8.91\end{array}$ \\
\hline $\log$ P value & $\begin{array}{l}\log \text { P } 2.69 \\
\log \text { P } 2.74\end{array}$ \\
\hline $\log$ S value & -3.1 \\
\hline
\end{tabular}

\section{Mechanism of Action:}

A small molecule of Apremilast is inhibitor of PDE4, an enzyme that break down cyclic adenosine monophosphate (cAMP), and it's the dominant enzyme responsible for this reaction in inflammatory cells. (5)

\section{Analytical techniques used for determination of apremilast:}

\section{A. High-performance liquid chromatography (HPLC):}

High performance liquid chromatography (HPLC) is one of todays most important instrument of analytical chemistry, derived from classical column chromatography. The concept is to inject a sample solution into a column of a permeable material (stationary phase), and pump a liquid (mobile phase) through the column at high pressure. The separation is based on differences in migration rates across column resulting from different sample partition between stationary and mobile phase elution happens at different times, depends on the separation behaviour of different components. (6)

The HPLC instrument involves pump, injector, column, detector, integrator and display system.

The technique of HPLC has following features.

\footnotetext{
$\checkmark$ Having higher resolution
}

$\checkmark$ Diameter is small, Stainless steel, Glass column

$\checkmark$ Rapid analysis

$\checkmark \quad$ Mobile phase pressure is higher

$\checkmark \quad$ Mobile phase having controlled flow rate (7)

Types of HPLC:

Its Depends on the substance used i.e. stationary phase used, the HPLC is divided into following types:

$\checkmark$ Normal Phase HPLC- on the basis of polarity the separation is done. Usually this phase is polar, silica is used mostly and Hexane is used as non- polar phase, also chloroform and diethyl ether. Mostly the polar samples are mounted on column.

$\checkmark \quad$ Reverse Phase HPLC- In this the mobile phase is polar and non-polar or hydrophobic is stationary phase. It is reverse to normal phase HPLC. The more is the nonpolar nature the more it will be retained on column.

$\checkmark$ Size-exclusion HPLC- The column must combine molecules with correctly regulated substrate. The constituent's separation will be based on the differences in molecular sizes.

$\checkmark \quad$ Ion-exchange HPLC- The stationary phase has, across to the sample charge, an ionically charged surface. The used mobile phase is an aqueous buffer that regulates pH and ionic strength. (8) 
Table 2: HPLC method for apremilast

\begin{tabular}{|c|c|c|c|c|c|c|c|c|}
\hline $\begin{array}{l}\text { Sr. } \\
\text { no. }\end{array}$ & Drug & Method & $\begin{array}{l}\text { Stationary } \\
\text { phase }\end{array}$ & $\begin{array}{l}\text { Mobile } \\
\text { phase }\end{array}$ & Detection/Detector & $\begin{array}{c}\text { Linearity, } \\
\text { LOD, LOQ } \\
(\mu \mathrm{g} / \mathrm{mL})\end{array}$ & $\mathbf{R}_{\mathbf{t}} / \mathbf{F}_{\mathbf{R}}$ & Ref \\
\hline 1 & Apremilast & $\begin{array}{l}\text { HPLC } \\
\text { (stability } \\
\text { indicating, } \\
\text { RS) }\end{array}$ & $\begin{array}{l}\text { Cosmosil C-18 } \\
\text { column } 250 \mathrm{~mm} \\
\text { x } 4.6 \mathrm{~mm}, 5.0 \mu \mathrm{m} \\
\text { with Guard } \\
\text { cartridge: Make; } \\
\text { Phenomenex } \\
\text { C18, } 4.0 \mathrm{~mm} \mathrm{x} \\
3.0 \mathrm{~mm}\end{array}$ & $\begin{array}{l}\text { Mobile } \\
\text { Phase-A: } \\
\text { Buffer-1: } \\
\text { Methanol } \\
(90: 10) \mathrm{v} / \mathrm{v} \\
\text { Mobile } \\
\text { Phase-B: } \\
\text { Buffer-1: } \\
\text { Acetonitrile } \\
(10: 90) \mathrm{v} / \mathrm{v}\end{array}$ & $\begin{array}{l}\text { 230nm. } \\
\text { PDA Detector }\end{array}$ & $\begin{array}{l}\text { Linearity: } \\
\text { 50\% to } 150 \% \\
\text { LOD:0.0012\% } \\
\text { LOQ:0.004\% }\end{array}$ & $\begin{array}{l}\mathrm{R}_{\mathrm{t}}: 1 \mathrm{~min} \\
\mathrm{~F}_{\mathrm{R}}: 1 \\
\mathrm{ml} / \mathrm{min}\end{array}$ & 1 \\
\hline 2 & Apremilast & RP-HPLC & $\begin{array}{l}\text { Grace C18 } \\
\text { column } \\
(250 \mathrm{~mm} \times 4.6, \\
\text { Particle size: } 5 \\
\text { micron) }\end{array}$ & $\begin{array}{l}\text { Methanol: } \\
\text { Water } \\
(80: 20)\end{array}$ & $\begin{array}{l}\text { 231nm } \\
\text { UV } 2450 \text { Double } \\
\text { Beam UV-Visible } \\
\text { spectrometer }\end{array}$ & $\begin{array}{l}\text { Linearity: 10- } \\
50 \mu \mathrm{g} / \mathrm{mL} \\
\text { LOD: - } \\
\text { LOQ: - }\end{array}$ & $\begin{array}{l}\mathrm{R}_{\mathrm{t}}: \\
4.80 \mathrm{~min} \\
\mathrm{~F}_{\mathrm{R}}: 0.8 \\
\mathrm{ml} / \mathrm{min}\end{array}$ & 3 \\
\hline 3 & Apremilast & HPLC & $\begin{array}{l}\text { Agilent C } 18 \text { ( } 4.6 \\
\text { mm } 250 \mathrm{~mm} .) \\
5 \mu \mathrm{m}\end{array}$ & $\begin{array}{l}\text { Acetonitrile: } \\
\text { Water } \\
(70: 30)\end{array}$ & $230 \mathrm{~nm}$ & $\begin{array}{l}\text { Linearity: } 2- \\
10 \mu \mathrm{g} / \mathrm{mL} \\
\text { LOD: } 0.2403 \\
\text { LOQ: } 0.72084\end{array}$ & $\begin{array}{l}\text { Rt: } \\
4.92 \mathrm{~min} \\
\mathrm{~F}_{\mathrm{R}}:- \\
\mathrm{ml} / \mathrm{min}\end{array}$ & 5 \\
\hline 4 & Apremilast & RP-HPLC & $\begin{array}{l}\text { Ultima C18 } \\
\text { column ( } 250 \\
\text { mm×4.6 mm, i.d., } \\
5 \text { am particle } \\
\text { size) }\end{array}$ & $\begin{array}{l}\text { Methanol: } \\
\text { Water } \\
(70: 30)\end{array}$ & $\begin{array}{l}\text { 231nm } \\
\text { Photo Diode Array }\end{array}$ & - & $\begin{array}{l}\mathrm{R}_{\mathrm{t}}: \\
5.15 \mathrm{~min} \\
\mathrm{~F}_{\mathrm{R}}: 1 \\
\mathrm{ml} / \mathrm{min}\end{array}$ & 24 \\
\hline 5 & Apremilast & $\begin{array}{l}\text { RP-LC } \\
\text { (stability } \\
\text { indicating) }\end{array}$ & $\begin{array}{l}\text { Synergi Max-RP } \\
80 \mathrm{~A}(150 \times 4.6 \\
\mathrm{mm} \text { ID), } 4 \mu\end{array}$ & $\begin{array}{l}\text { Mobile phase } \\
\text { A: Phosphate } \\
\text { Buffer } \\
\text { Mobile Phase } \\
\text { B: ACN }\end{array}$ & $\begin{array}{l}230 \mathrm{~nm} \\
\text { photodiode array } \\
\text { detector }\end{array}$ & $\begin{array}{l}\text { Linearity : } \\
50 \%-250 \% \\
\text { LOD: }-0.053 \\
\mu \mathrm{g} / \mathrm{ml}^{-1} \\
\text { LOQ: }-0.160 \\
\mu \mathrm{g} / \mathrm{ml}^{-1}\end{array}$ & $\begin{array}{l}\mathrm{R}_{\mathrm{t}}: \\
13.66 \mathrm{~min} \\
\mathrm{~F}_{\mathrm{R}}: 1 \\
\mathrm{ml} / \mathrm{min}\end{array}$ & 25 \\
\hline
\end{tabular}

\section{B. UV-visible spectrophotometric method:}

UV-Visible spectrophotometry is mostly used method in pharmaceutical research. This means calculating how much ultraviolet or visible radiation a material absorbs in solution. Ultraviolet-Visible spectrophotometers are the instruments that compute the correlation or function of the correlation of the intensity of two light beams in the UV-Visible region. Using a spectrophotometer, organic compounds can be detected in qualitative analysis, if any reported data are available, and significant spectrophotometric examination is used to determine the amount of molecular species absorbing the radiation. Spectrophotometric technique is simple, fast, relatively precise, and applicable to small compound quantities. The Beer-Lambert law is the fundamental law governing quantitative spectrophotometric analysis.

Beer's law: It states that the intensity of a parallel monochro matic radiation beam decreases exponentially with the numb er of molecules that are absorbed. To put it another way, abs orbance is proportionate to concentration.

Lambert's law: It states that the frequency of a parallel mono chromatic radiation beam diminishes exponentially as it trav els through a homogeneous thickness medium. Combining th ese two laws gives rise to the Beer-Lambert law.

Table 3: Regions of electromagnetic spectrum.

\begin{tabular}{|l|l|}
\hline Region & Wavelength \\
\hline Far (or vacuum) ultraviolet & $10-200 \mathrm{~nm}$ \\
\hline Near ultraviolet & $200-400 \mathrm{~nm}$ \\
\hline Visible & $400-750 \mathrm{~nm}$ \\
\hline Near infrared & $0.75-2.2 \mu \mathrm{m}$ \\
\hline Mid infrared & $2.5-50 \mu \mathrm{m}$ \\
\hline Far infrared & $50-1000 \mu \mathrm{m}$ \\
\hline
\end{tabular}


Beer-Lambert law:

If light beam is passed through a translucent cell containing an an absorbing compound solution, there ma $\mathrm{y}$ be a decrease in light intensity. The BeerLambert Law is ex pressed in mathematical terms as

$A=a b c$

Where,

$$
\begin{aligned}
& A=\text { absorbance or optical density } \\
& a=\text { absorptivity or extinction coefficient } \\
& b=\text { path length of radiation through sample }(\mathrm{cm}) \\
& c=\text { concentration of solute in solution. }
\end{aligned}
$$

\begin{tabular}{|c|c|c|c|c|c|c|c|}
\hline $\begin{array}{l}\text { Sr. } \\
\text { No. }\end{array}$ & Drug & Matrix & Method & Solvent & Detection & Linearity/ LOD, LOQ & Ref. \\
\hline 1 & Apremilast & API & $\begin{array}{l}\text { A double beam UV- } \\
\text { visible } \\
\text { spectrophotometer }\end{array}$ & $\begin{array}{l}\text { Water and } \\
\text { Methanol }\end{array}$ & $230 \mathrm{~nm}$ & $\begin{array}{l}\text { Linearity: } 2-10 \mu \mathrm{g} / \mathrm{mL} \\
\qquad \mathrm{R}^{2}: 0.999 \\
\text { LOD: }--\mu \mathrm{g} / \mathrm{mL} \\
\text { LOQ: }--\mu \mathrm{g} / \mathrm{mL}\end{array}$ & 28 \\
\hline 2 & Apremilast & $\begin{array}{l}\text { Bulk and } \\
\text { laboratory } \\
\text { prepared } \\
\text { mixture. }\end{array}$ & $\begin{array}{l}\text { A double beam UV } \\
1700 \text { Pharmaspec }\end{array}$ & Methanol & $\begin{array}{l}\text { Method A: } \\
230 \mathrm{~nm} \\
\text { Method B: } \\
224 \mathrm{~nm} \\
\text { Method C: } \\
225- \\
235 \mathrm{~nm}\end{array}$ & 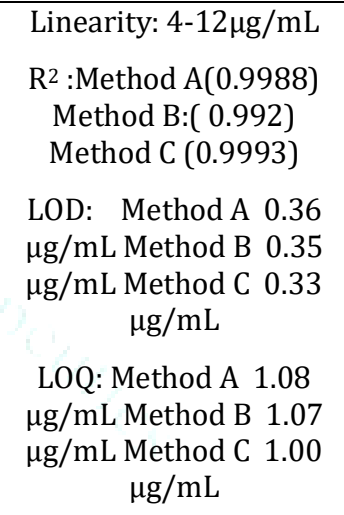 & 29 \\
\hline 3 & Apremilast & $\begin{array}{l}\text { Bulk and } \\
\text { Tablet } \\
\text { Dosage } \\
\text { Form }\end{array}$ & $\begin{array}{c}\text { UV- } \\
\text { Spectrophotometer } \\
\text { (Systronic-2201) }\end{array}$ & Acetonitrile & $230 \mathrm{~nm}$ & $\begin{array}{c}\text { Linearity: } 2-10 \mu \mathrm{g} / \mathrm{mL} \\
\mathrm{R}^{2}: 0.9995 \\
\text { LOD: } 0.2403 \mu \mathrm{g} / \mathrm{ML} \\
\text { LOQ: } 0.72084 \mu \mathrm{g} / \mathrm{mL}\end{array}$ & 30 \\
\hline 4 & Apremilast & Bulk drug & $\begin{array}{l}\text { Jasco double beam } \\
\text { UV-visible } \\
\text { spectrophotometer, } \\
\text { Model: V-630 }\end{array}$ & Methanol. & $230 \mathrm{~nm}$ & $\begin{array}{c}\text { Linearity: } 1-7 \mu \mathrm{g} / \mathrm{ml} . \mathrm{R}^{2} \text { : } \\
0.9991 \\
\text { LOD: } 0.288 \mu \mathrm{g} / \mathrm{mL} \\
\text { LOQ: } 0.874 \mu \mathrm{g} / \mathrm{mL}\end{array}$ & 31 \\
\hline
\end{tabular}

Both $\mathrm{b}$ and $\mathrm{a}$ are constant so $\mathrm{a}$ is directly proportional to the concentration c. (9)

Table 4: UV- Spectrometric Method for Apremilast.

\section{High performance thin layer chromatography (HPTLC):}

Modern TLC, which carried out on pre-coated layers with instruments and mainly for quantification is widely understood and practical as HPTLC. Therefore, TLC and HPLC terminology are used interchangeably here. To teach the principal of chromatography, almost all over the world, TLC is used. The prime reasons for this preference are transparency of the sample during chromatography, simplicity to perform, and ultra-low-cost equipment for demonstration. A popular approach for increase resolution under capillary flow-controlled conditions is to use various developments. For planar chromatography, either onedimensional or two-dimensional separations are possible. Mobile phase velocity can also be manage by external method, such as in forced-flow development. HPTLC is the fastest form of chromatography, since sample chromatography is performed in parallel. Being offline, i.e. each step of the process is carried out independently, makes TLC / HPTLC not only faster but also versatile adequate for one HPTLC system to analyse individual samples by side by side. Stationary and mobile phase intake is directly proportional to the number of analysed samples.

The cost for analysis is low. One $20 \times 10 \mathrm{~cm}$ plate can accept about 20 samples and needs a mobile phase of $15 \mathrm{ml}$. For TLC / HPTLC the disposable stationary process has two distinct advantages in the preparation of samples. One sample can be washed on the plate itself. The other is that sample cleaning may not be necessary because the residual residue is inconsistent. Although the Silica gel is the most commonly used adsorbent (stationary phase), many other adsorbents have been used as a separation medium such as reverse phases, bonding phases, alumina, Kieselguhr, etc. Some solvents can be used during the mobile phase since the 
coating can be disposed of. Gas phase also plays a prime role in TLC/HPTLC in the developing chamber's vapor saturation, its $\mathrm{pH}$, and humidity in the developing chamber.

For quantitative, semi-quantitative and qualitative analysis, TLC and HPTLC may be used. It can also be used after chromatographic separation for the identification of industrial fractions and for the identification of herbal extracts, complex mixtures by "HPTLC fingerprint". Many laboratories use TLC/HPTLC for the analysis, checking or comparison of impurities with related samples, screening of unidentified samples. TLC / HPTLC is a functional tool for daily analysis: quality control, scientific R\&D, process monitoring and environmental laboratories. (10-13)

Table 5: HPTLC method for apremilast.

\begin{tabular}{|c|c|c|c|c|c|c|c|}
\hline $\begin{array}{l}\text { Sr. } \\
\text { no }\end{array}$ & $\begin{array}{l}\text { Drug and } \\
\text { Matrix }\end{array}$ & $\begin{array}{c}\text { Stationary } \\
\text { phase }\end{array}$ & Mobile phase & $\begin{array}{c}\text { Chamber } \\
\text { saturation/ TLC } \\
\text { plate } \\
\text { development } \\
\text { time }\end{array}$ & Detection & $\begin{array}{c}\text { Linearity, LOD, } \\
\text { LOQ } \\
(\mu \mathrm{g} / \mathrm{mL})\end{array}$ & Ref. \\
\hline 1 & $\begin{array}{l}\text { Apremilast } \\
\text { (Bulk and in- } \\
\text { house tablet) }\end{array}$ & $\begin{array}{c}\text { Aluminium } \\
\text { backed } \\
\text { precoated silica } \\
\text { gel } 60-\mathrm{F} 254(20 \\
\text { x } 10 \mathrm{~cm})\end{array}$ & $\begin{array}{c}\text { Toluene: } \\
\text { Methanol (8:2 } \\
\text { v/v) }\end{array}$ & $\begin{array}{c}\text { CSt: } 25 \mathrm{~min} \\
\text { PDt: } 8 \mathrm{~min} \\
\text { Rf value: } 0.64 \pm \\
0.05\end{array}$ & $\begin{array}{c}\text { Densitometry } \\
\text { scanning at } \\
230 \mathrm{~nm}\end{array}$ & $\begin{array}{c}\text { Linearity: } 250- \\
1500 \mathrm{ng} / \mathrm{band} \\
\text { R}^{2}: 0.998 \\
\text { LOD- (DL) } 3.3 \mathrm{NB} \\
\text { LOQ- } \\
\text { (QL) } 10 \mathrm{NB}\end{array}$ & 26 \\
\hline 2 & Apremilast & $\begin{array}{c}\text { Aluminium TLC } \\
\text { plate precoated } \\
\text { with silica gel } 60 \\
\text { F254 (10 x } 10 \\
\text { cm) }\end{array}$ & $\begin{array}{l}\text { Toluene: Ethyl } \\
\text { Acetate } \\
(4: 6 \mathrm{v} / \mathrm{v})\end{array}$ & $\begin{array}{l}\text { CSt: } 15 \mathrm{~min} \\
\text { PDt: } 10 \mathrm{~min} \\
\text { Rf value: } \\
0.55 \pm 0.02 \text {. } \\
\end{array}$ & $\begin{array}{c}\text { Densitometry } \\
\text { scanning at } \\
236 \mathrm{~nm}\end{array}$ & $\begin{array}{c}\text { Linearity: } 100- \\
600 \mathrm{ng} / \text { band } \\
\mathrm{R}^{2}: 0.9978 \\
\text { LOD- } \\
0.7782 \mathrm{ng} / \text { band } \\
\text { LOQ- } \\
2.3583 \mathrm{ng} / \text { band }\end{array}$ & 27 \\
\hline
\end{tabular}

\section{Stability indicating method:}

Chemical stability of pharmaceutical substances is of great concern, as it influences the drug product's safety and effectiveness. The FDA and ICH guidelines state the need for stability testing data to determine how the nature of a drug substance and drug product changes over time under the effect of different environmental factors. The ICH guideline notes that stress testing is intended to identify the likely degradation products which further assist in determining the molecule's intrinsic stability and identifying pathways of degradation, and confirm the stabilization indicating procedures used. (14-15)

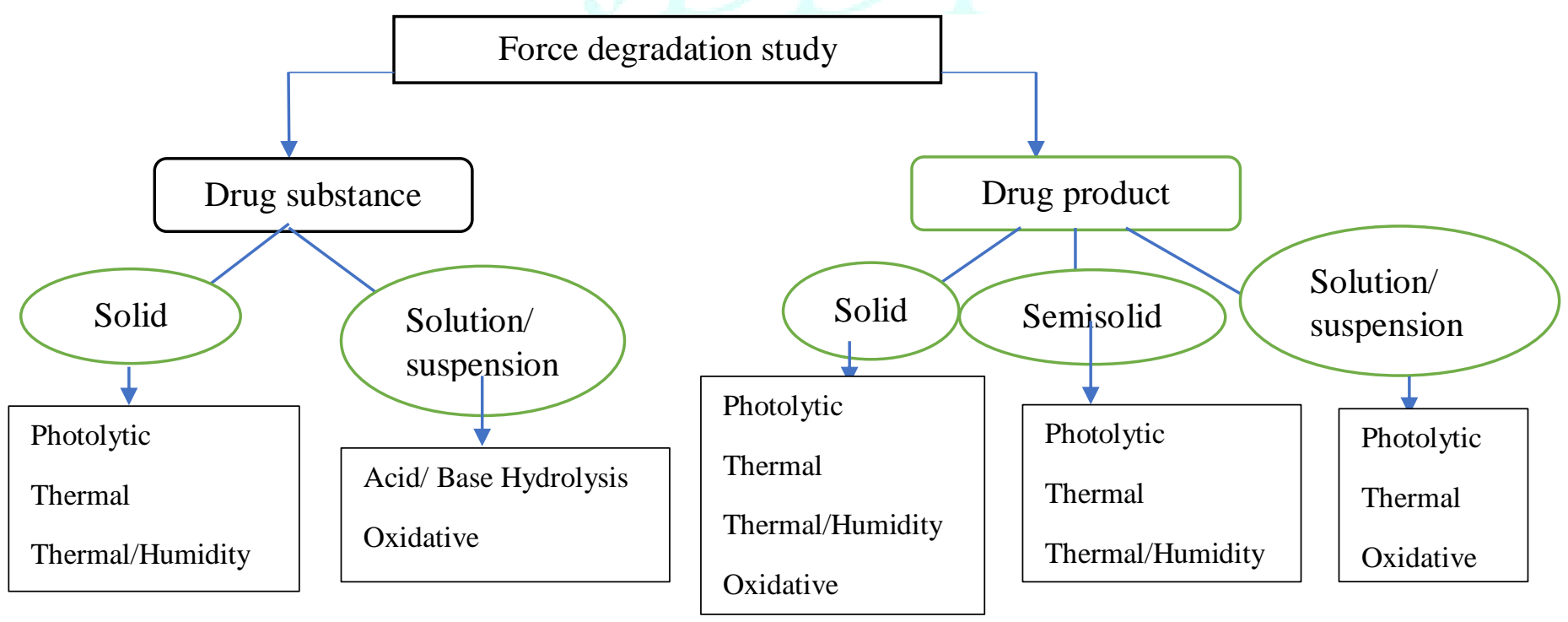

Scheme 1: An illustrative flowchart describing various stress conditions used for degradation of drug substance and drug product. 
Table 6: Conditions generally employed for forced degradation (16).

\begin{tabular}{|c|c|c|c|}
\hline Degradation Type & Experimental Conditions & Storage Conditions & Sampling Time (days) \\
\hline \multirow[t]{6}{*}{ Hydrolysis } & Control API (no acid or base) & $40^{\circ} \mathrm{C}, 60^{\circ} \mathrm{C}$ & 1,3,5 Days \\
\hline & $0.1 \mathrm{~N} \mathrm{HCl}$ & $40^{\circ} \mathrm{C}, 60^{\circ} \mathrm{C}$ & 1,3,5 Days \\
\hline & $0.1 \mathrm{~N} \mathrm{NaOH}$ & $40^{\circ} \mathrm{C}, 60^{\circ} \mathrm{C}$ & 1,3,5 Days \\
\hline & Acid control (no API) & $40^{\circ} \mathrm{C}, 60^{\circ} \mathrm{C}$ & 1,3,5 Days \\
\hline & Base control (no API) & $40^{\circ} \mathrm{C}, 60^{\circ} \mathrm{C}$ & 1,3,5 Days \\
\hline & pH: $2,4,6,8$ & $40^{\circ} \mathrm{C}, 60^{\circ} \mathrm{C}$ & 1,3,5 Days \\
\hline \multirow[t]{4}{*}{ Oxidation } & $3 \% \mathrm{H}_{2} \mathrm{O}_{2}$ & $25^{\circ} \mathrm{C}, 60^{\circ} \mathrm{C}$ & 1,3,5 Days \\
\hline & Peroxide control & $25^{\circ} \mathrm{C}, 60^{\circ} \mathrm{C}$ & 1,3,5 Days \\
\hline & Azobisisobutyronitrile (AIBN) & $40^{\circ} \mathrm{C}, 60^{\circ} \mathrm{C}$ & 1,3,5 Days \\
\hline & AIBN control & $40^{\circ} \mathrm{C}, 60^{\circ} \mathrm{C}$ & 1,3,5 Days \\
\hline \multirow[t]{3}{*}{ Photolytic } & Light, 1 X ICH & NA & 1,3,5 Days \\
\hline & Light, 3 X ICH & NA & 1,3,5 Days \\
\hline & Light control & NA & 1,3,5 Days \\
\hline \multirow[t]{5}{*}{ Thermal } & Heat chamber & $60^{\circ} \mathrm{C}$ & 1,3,5 Days \\
\hline & Heat chamber & $60^{\circ} \mathrm{C} / 75 \% \mathrm{RH}$ & 1,3,5 Days \\
\hline & Heat chamber & $80^{\circ} \mathrm{C}$ & 1,3,5 Days \\
\hline & Heat chamber & $80{ }^{\circ} \mathrm{C} / 75 \% \mathrm{RH}$ & 1,3,5 Days \\
\hline & Heat control & Room temp. & 1,3,5 Days \\
\hline
\end{tabular}

Table 7: stability indicating method for Apremilast

\begin{tabular}{|c|c|c|c|c|c|c|c|c|}
\hline $\begin{array}{l}\text { Sr. } \\
\text { no. }\end{array}$ & Drug & Method & $\begin{array}{c}\text { Stationary } \\
\text { phase }\end{array}$ & $\begin{array}{l}\text { Mobile } \\
\text { phase/ } \\
\text { Solvent }\end{array}$ & Detection/Detector & $\begin{array}{c}\text { Linearity, } \\
\text { LOD, LOQ } \\
(\mu \mathrm{g} / \mathrm{mL})\end{array}$ & $\mathbf{R}_{\mathbf{t}} / \mathbf{F}_{\mathbf{R}}$ & Ref. \\
\hline 1 & Apremilast & RP-HPLC & $\begin{array}{l}\text { Grace C18 } \\
(250 \mathrm{~mm} \mathrm{x} \\
4.6 \mathrm{ID}, 5 \mu \mathrm{m})\end{array}$ & $\begin{array}{l}\text { Methanol: } \\
\text { Water } \\
(70: 30)\end{array}$ & $\begin{array}{l}\text { 230nm } \\
\text { UV-3000-M detector }\end{array}$ & $\begin{array}{l}\text { Linearity: } 10- \\
50 \mu \mathrm{g} / \mathrm{ml} \\
\text { LOD: - } 0.5329 \\
\mu \mathrm{g} / \mathrm{ml} \\
\mathrm{LOQ}:-1.615 \\
\mu \mathrm{g} / \mathrm{ml}\end{array}$ & $\begin{array}{l}\mathrm{R}_{\mathrm{t}}: 5.20 \mathrm{~min} \\
\mathrm{~F}_{\mathrm{R}}:-0.8 \\
\mathrm{ml} / \mathrm{min}\end{array}$ & 34 \\
\hline 2 & Apremilast & RP-HPLC & $\begin{array}{l}\text { Inertsil C8 } \\
(250 \times 4.6 \\
\text { mm) } 5 \mu\end{array}$ & $\begin{array}{l}\text { Buffer and } \\
\text { Methanol } \\
(47: 53 \% \\
\text { v/v) }\end{array}$ & $\begin{array}{l}230 \mathrm{~nm} \text { Diode } \\
\text { array detector }\end{array}$ & - & $\begin{array}{l}\text { Rt: } 8.3 \mathrm{~min} \\
\mathrm{~F}_{\mathrm{R}}:-1.5 \\
\mathrm{ml} / \mathrm{min}\end{array}$ & 35 \\
\hline 3 & Apremilast & UV & - & Acetonitrile & $\begin{array}{l}229.3 \mathrm{~nm} \\
\text { ELICO Double beam } \\
\text { SL } 210 \text { Ultra violet - } \\
\text { Visible } \\
\text { spectrophotometer }\end{array}$ & $\begin{array}{l}\text { Linearity: 2- } \\
10 \mu \mathrm{g} / \mathrm{mL} \\
\mathrm{R}^{2}: 0.9983 \\
\text { LOD: } \\
0.0027 \mu \mathrm{g} / \mathrm{mL} \\
\mathrm{LOQ:} \\
0.0082 \mu \mathrm{g} / \mathrm{mL}\end{array}$ & - & 36 \\
\hline 4 & Apremilast & UV & - & Methanol. & $\begin{array}{l}220 \mathrm{~nm} \\
\text { Methanol. UV - } \\
\text { Visible } \\
\text { spectrophotometer } \\
\text { (Shimadzu Model } \\
\text { 1700) }\end{array}$ & $\begin{array}{l}\text { Linearity: } 20- \\
100 \mu \mathrm{g} / \mathrm{ml} \\
\mathrm{R}^{2}: 0.999 \\
\text { LOD: }--\mu \mathrm{g} / \mathrm{mL} \\
\mathrm{LOQ}:--\mu \mathrm{g} / \mathrm{mL}\end{array}$ & - & 37 \\
\hline
\end{tabular}




\section{E. Bio-analytical method:}

Bioanalysis is a process used to evaluate concentrations in bi ological samples such as blood, plasma, serum cerebrospinal fluids and urine, as well as saliva for their metabolites and/o r endogenic substances. (17-20) The accuracy of these trials depends directly on the standard of the bioanalytical data behind them. It is therefore important that guiding principles are organize and disseminated to the pharmaceutical community for the validation of these analytical methods. For bioanalysis of drug in plasma Both RP - HPLC and LC MS-MS can be used. The instruments have its own merits. For evaluation of a lot of compounds RP - HPLC coupled with UV, PDA or fluorescence detector. These chromatographic principles give main advantages including low detection limits, the potential to produce structural information, a need for least sample treatment and the probability to cover a broad range of polarity analytes, all procedures for validating the bioanalytical methods include procedures that show that a certain process is used to measure the analytes quantitatively. Selectivity, precision, linearity, detection limit, quantity limit, recovery, power, stability and range are main parameters for this validation. (21-22)

The process by which routine sample analysis can be classify into:

\section{Reference standard preparation,}

2. Development of bioanalytical method and formation of assay procedure and

3. For routine drug analysis. Application of validated bioanalytical method and acceptance criteria for the analytical run and/or batch (23).

Table 8: Bioanalytical method for Apremilast.

\begin{tabular}{|c|c|c|c|c|c|c|c|c|c|}
\hline Sr.no & Method & Drug & $\begin{array}{l}\text { Bio- } \\
\text { fluid }\end{array}$ & Column & Mob. phase & $\begin{array}{l}\text { F.R and } \\
\text { R. T }\end{array}$ & $\begin{array}{l}\text { Detection } \\
\text { /detector }\end{array}$ & $\begin{array}{c}\text { Linearity \& } \\
\text { LOD\&LOQ }\end{array}$ & Ref. \\
\hline 1 & $\begin{array}{l}\text { UPLC/MS- } \\
\text { MS }\end{array}$ & Apremilast & $\begin{array}{l}\text { Rat } \\
\text { plasma }\end{array}$ & $\begin{array}{l}\text { Acquity } \\
\text { BEHTM } \\
\text { C18 } \\
\text { column } \\
(100 \times 2.1 \\
\mathrm{mm}, 1.7 \\
\mu \mathrm{m})\end{array}$ & $\begin{array}{l}\text { Acetonitrile: } \\
\text { ammonia(85:15) }\end{array}$ & $\begin{array}{l}\text { F.R : } 0.3 \\
\mathrm{~mL} / \mathrm{min} \\
\text { R.T } \\
: 0.81\end{array}$ & $\begin{array}{l}\text { MRM } \\
\text { detection }\end{array}$ & $\begin{array}{l}\text { Linearity: } \\
3.04 \text { and } \\
1000 \mathrm{ng} / \mathrm{ml} \\
\mathrm{R}^{2}: 0.995 \\
\text { LOD: - } \\
\text { LLOQ: } 3.04 \\
\mathrm{ng} / \mathrm{ml}\end{array}$ & 32 \\
\hline 2 & $\begin{array}{l}\text { UPLC/MS- } \\
\text { MS }\end{array}$ & Apremilast & $\begin{array}{l}\text { Rat } \\
\text { plasma }\end{array}$ & $\begin{array}{l}\text { Acquity } \\
\text { BEH } \\
\text { C18column } \\
(2.1 \\
\mathrm{mm} \times 50 \\
\mathrm{~mm}, 1.7 \\
\mu \mathrm{m} \\
\text { particle } \\
\text { size) }\end{array}$ & $\begin{array}{l}\text { Solvent -A ( } 0.1 \% \\
\text { formic acid in } \\
\text { water) } \\
\text { Solvent B - } \\
\text { acetonitrile }\end{array}$ & $\begin{array}{l}\text { F.R : } \\
0.40 \\
\mathrm{~mL} / \mathrm{min} \\
\text { R.T : - }\end{array}$ & $\begin{array}{l}\text { XEVO TQD } \\
\text { triple } \\
\text { quadruple } \\
\text { mass } \\
\text { spectrometer } \\
\text { with an } \\
\text { electro-spray } \\
\text { ionization } \\
\text { (ESI) }\end{array}$ & $\begin{array}{l}\text { Linearity: } 0.1 \\
\text { and } 100 \\
\mathrm{ng} / \mathrm{ml} \\
\mathrm{R}^{2}: 0.9914 \\
\text { LOD: - } \\
\text { LLOQ: } \\
0.1 \mathrm{ng} / \mathrm{ml}\end{array}$ & 33 \\
\hline
\end{tabular}

\section{Conclusion}

The present review illustrates various analytical approaches exercised for the evaluation of Apremilast. A numerous investigation had perform including, Bio-analytical, Stability indicating, HPLC, HPTLC, UV-Visible Spectroscopy, and LCMS, etc. for evaluation of Apremilast in bulk and in its combined pharmaceutical formulations and in plasma. Liquid chromatography with UV detection has been found to be most studied for Apremilast in bulk as well as pharmaceutical dosage forms, while hyphenated such as LCMS methods are reported for determination of Apremilast and its metabolite in plasma and other biological fluids. Few chromatography approaches like HPTLC and UV Spectrophotometry methods are also used for assay of Apremilast.

\section{References:}

1. Anerao A, Telange V, Bondre N, John S, Gadhave T, Pradhan N International Journal of Current Medical and Pharmaceutical Research.

2. Badhe P, Aher S, Saudagar RB. Analytical Method of Apremilast: A Review. Journal of Drug Delivery and Therapeutics. 2019 Jun 29;9(3-s):1116-9.

3. Rina Mohan Sonawane, Rutuja Prabhakar Sonare, Snehal Ganpat Tekawade And Dr. Ashok Pandurang Pingle.
Chromatographic Method Development and Validation of Assay of Apremilast In Bulk and Tablet Dosage Form Ejbps, 2018, Volume 5, Issue 8, 412-417.

4. European Medicines Agency (EMA). Assessment report: Otezla. International non-proprietary name: apremilast.

5. Hemaraj R. Patil, Dr. S. T. Patil, V. H. Jain And Dr. S. P. Pawar. Devlopment And Validation of UV-Spectrophotometric and Hplc Method for Apremilast In Bulk and Tablet Dosage Form. Ejpmr, 2019,6(8), 233-239

6. Gupta V, Jain AD, Gill NS, Gupta K. Development and validation of HPLC method-a review. Int. Res J Pharm. App Sci. 2012;2(4):17-25.

7. Bhardwaj SK, Dwivedia K, Agarwala DD. A review: HPLC method development and validation. International Journal of Analytical and Bioanalytical Chemistry. 2015;5(4):76-81.

8. Thammana M. A review on high performance liquid chromatography (HPLC). Res Rev J Pharm Anal RRJPA. 2016;5(2):22-8.

9. Behera S, Ghanty S, Ahmad F, Santra S, Banerjee S. UV-visible spectrophotometric method development and validation of assay of paracetamol tablet formulation. J Anal Bioanal Techniques. 2012;3(6):151-7.

10. Jain A, Parashar AK, Nema RK, Narsinghani T. High Performance Thin Layer Chromatography (HPTLC): A Modern Analytical Tool for Chemical Analysis. Current Research in Pharmaceutical Sciences. 2014 Mar 30:8-14.

11. Sharma J. Chromatographic Methods of Analysis: Thin Layer Chromatography. In Encyclopedia of Pharmaceutical 
Technology; Swarbrick J (Ed.), Information Healthcare (2007) (Pp. 538-550).

12. Reich E, Schibli A and Debatt A. Validation of HighPerformance Thin-Layer Chromatographic Methods for The Identification of Botanicals in A Cgmp Environment. J AOAC Int. 2008; 91:13-20.

13. Renger B. Contemporary Thin Layer Chromatography in Pharmaceutical Analysis. J AOAC Int.1998; 81: 333-339.

14. Blessy MR, Patel RD, Prajapati PN, Agrawal YK. Development of forced degradation and stability indicating studies of drugs-A review. Journal of pharmaceutical analysis. 2014 Jun 1;4(3):159-65.

15. ICH Guidelines, Q1A (R2): Stability Testing of New Drug Substances and Products (Revision 2)

16. Patel Riddhiben M, Patel Piyushbhai M, Patel Natubhai M. Stability indicating HPLC method development-a review. International Research Journal of Pharmacy2011. 2011.

17. Pushpa Latha E, Sailaja B. Bioanalytical method development and validation by HPLC: a review. J Appl Pharm. 2014 Dec; 1:1-9.

18. Abdul Rahman MM, Kalyani Rupnawar, Madhuri A. Nagras And Supriya A. Unavane. A Review on Bioanalytical Method Development, Validation and Techniques Used for Pharmacokinetic Studies Using LCMS/MS, Contemporary Investigations and Observations in Pharmacy, 2012, 1(2), $63-$ 71.

19. Pulido A, Ruisánchez I, Boqué R, Rius FX. Uncertainty of results in routine qualitative analysis. TrAC Trends in Analytical Chemistry. 2003 Oct 1;22(9):647-54.

20. Http://Www.Fda.Gov/Downloads/Drugs/Guidances/Ucm 070107.Pdf.

21. Kirthi A, Shanmugam R, Prathyusha MS, Basha DJ. A review on bioanalytical method development and validation by RP-HPLC. Journal of global trends in pharmaceutical sciences. 2014;5(4):2265-71.

22. Kalakuntla RR, Kumar KS. Bioanalytical method validation: A quality assurance auditor view point. Journal of Pharmaceutical Sciences and Research. 2009 Sep 1;1(3):1.

23. Tiwari G, Tiwari R. Bioanalytical method validation: An updated review. Pharmaceutical methods. 2010 Oct 1;1(1):2538.

24. Chaudhari SR, Shirkhedkar AA. Design of experiment avenue for development and validation of RP-HPLC-PDA method for determination of apremilast in bulk and in in-house tablet formulation. Journal of Analytical Science and Technology. 2019 Dec 1;10(1):10.

25. Landge SB, Dahale SB, Jadhav SA, Solanki PV, Bembalkar SR, Mathad VT. Development and validation of stability indicating rapid RP-LC method for determination of process and degradation related impurities of Apremilast, an antiinflammatory drug. American Journal of Analytical Chemistry. 2017 Jun 12;8(6):380-94.

26. Chaudhari SR, Shirkhedkar AA. Application of Box-Behnken Design for Validation of High Performance Thin-Layer
Chromatography/Densitometry Method for Robustness Determination of Apremilast in Bulk and inhouse Tablets. Pharmaceutical Methods. 2018 Jan 1;9(1).

27. Bhole RP, Naksakhare SR, Bonde CG. A Stability Indicating HPTLC Method for Apremilast and Identification of degradation products using MS/MS. Journal of Pharmaceutical Sciences and Research. 2019 May 1;11(5):1861-9.

28. Chakravarthy AV, Sailaja BB, Kumar PA. Method development and validation of ultraviolet-visible spectroscopic method for the estimation of assay of sugammadex sodium, Apremilast, riociguat, and vorapaxar sulfate drugs in active pharmaceutical ingredient form. Asian J Pharm Clin Res. 2017;10(2):241-50.

29. Intwala JK, Doshi DB. DEVELOPMENT AND VALIDATION OF SOPHISTICATED ANALYTICAL METHOD FOR THE ESTIMATION OF APREMILAST. Pharma Science Monitor. 2017 Apr 1;8(2).

30. Hemaraj R. Patil, Dr. S. T. Patil, V. H. Jain And Dr. S. P. Pawar. Devlopment And Validation of Uv-Spectrophotometric and Hplc Method for Apremilast In Bulk and Tablet Dosage Form. Ejpmr, 2019,6(8), 233-239

31. Lonkar NA, Dole MN, Sawant SD. Development and validation of UV spectrophotometric method for the estimation of apremilast in bulk form by absorbance maxima method. World J Pharm Pharm Sci. 2017 Apr 22; 6(7):758-66.

32. Iqbal M, Ezzeldin E, Al-Rashood ST, Imam F, Al-Rashood KA. Determination of apremilast in rat plasma by UPLC-MS/MS in ESI-negative mode to avoid adduct ions formation. Bioanalysis. 2016 Jul;8(14):1499-508.

33. Chen LG, Wang Z, Wang S, Li T, Pan Y, Lai X. Determination of apremilast in rat plasma by UPLC-MS-MS and its application to a pharmacokinetic study. Journal of chromatographic science. 2016 Sep 1;54(8):1336-40.

34. Lonkar, N., Sawant, S. And Dole, M. Development and Validation of Stability Indicating RP-HPLC Method for The Estimation of Apremilast By Forced Degradation Studies. W. J Pharm Pharm Sci. 2017a, 6, Pp.1493-502.

35. Rajan V Rele and Patil SP. Reversed Phase High Performance Liquid Chromatography Method for Determination of Assay and Forced Degradation Study of Apremilast From Active Pharmaceutical Dosage Form. Journal of Chemical and Pharmaceutical Research, 2018, 10(7): 139-144

36. Ravisankar P, Sulthana MS, Babu PS. Development and validation of stability-indicating UV spectrophotometric method for determination of Apremilast in bulk and pharmaceutical dosage form. Ind J Res Pharm Biotechnol. 2017; 5:47.

37. Kulsum S, Sagar GV, Butul A, Fatima S, Uddin S. Method development and validation of forced degradation studies of apremilast by using UV spectrophotometric method. World Journal of Pharmacy and Pharmaceutical Sciences. 2016;5(6):1595-601. 